\title{
PENGARUH KEPUASAN KERJA DAN BEBAN KERJA TERHADAP PRESTASI KERJA HOTEL SUDI MAMPIR BLOK SONGO LABUHANBATU SELATAN
}

\author{
Nirma Andini ${ }^{1}$, Ali Sahputra ${ }^{2}$ \\ ${ }^{1}$ Alumni Sarjana Ekonomi STIE Labuhanbatu \\ ${ }^{2}$ Dosen STIE Labuhanbatu
}

\begin{abstract}
ABSTRAK
Peran karyawan sangat penting dalam sebuah perusahaan, oleh sebab itu perusahaan harus dapat menciptakan suasana kondusif bagi setiap aktivitas perusahaan, agar para karyawan tersebut dapat memberikan prestasi kerja yang optimal bagi perusahaan. Jika para karyawan telah memberikan prestasi kerja terbaiknya, tentu akan berdampak pada peningkatan produktivitas perusahaan. Penelitian ini bertujuan untuk menganalisis pengaruh secara parsial kepuasan kerja terhadap prestasi kerja. Untuk menganalisis pengaruh secara parsial beban kerja terhadap prestasi kerja. Untuk menganalisis pengaruh secara serempak kepuasan kerja dan beban kerja terhadap prestasi kerja. Lokasi penelitian ini dilakukan pada Hotel Sudi Mampir Blok Songo Jalan Lintas Sumatera-Labuhanbatu Selatan. Populasi penelitian ini adalah karyawan Hotel Sudi Mampir Blok Songo yang berjumlah 40 orang. Teknik pengambilan sampel untuk menentukan sampel yang akan digunakan dalam penelitian ini menggunakan teknik sampling jenuh (sensus), yaitu metode pengambilan sampel dimana seluruh populasi dianggap sebagai sampel. Teknik pengumpulan data dilakukan dengan kuesioner atau data sekunder. Teknik analisis data menggunakan analisis regresi linier berganda dengan software SPSS. Hasil penelitian menunjukkan secara parsial kepuasan kerja memiliki pengaruh positif dan sangat signifikan terhadap prestasi kerja, secara parsial beban kerja memiliki pengaruh positif dan sangat signifikan terhadap prestasi kerja dan secara serempak kepuasan kerja dan beban kerja memiliki pengaruh positif dan sangat signifikan terhadap prestasi kerja.
\end{abstract}

Kata Kunci : Kepuasan Kerja, Beban Kerja, Prestasi Kerja.

\section{PENDAHULUAN}

\section{Latar Belakang Masalah}

Perusahaan yang mampu bersaing adalah perusahaan yang dinilai siap dari berbagai aspek, baik aspek internal maupun aspek eksternal. Oleh sebab itu manajemen dalam perusahaan tersebut, harus memiliki sumber daya manusia yang memiliki kemampuan dan keterampilan dalam menangani segala permasalahan yang ada pada perusahaan tersebut. Dengan demikian, perusahaan akan mampu berkompetisi dengan pesaing lain dengan kemampuan dan kualitas yang dimilikinya.

Peran karyawan sangat penting dalam sebuah perusahaan, oleh sebab itu perusahaan harus dapat menciptakan suasana kondusif bagi setiap aktivitas perusahaan, agar para karyawan tersebut dapat memberikan prestasi kerja yang optimal bagi perusahaan. Prestasi kerja karyawan merupakan tingkat pelaksanaan tugas yang dapat dicapai seseorang, unit, 
atau divisi dengan menggunakan kemampuan yang ada dan batasanbatasan yang telah ditetapkan untuk mencapai tujuan organisasi atau perusahaan.

Menurut Yuniastuti (2011) hasil penelitiannya membuktikan bahwa prestasi kerja karyawan dapat dipengaruhi oleh variabel kepuasan kerja. Kepuasan kerja dalam hal apapun sangat penting karena kecenderungan untuk meningkatkan prestasi kerja karyawan dalam perusahaan tidak akan dapat tercapai tanpa adanya kepuasan kerja karyawan.

Tugas dan tanggungjawab karyawan merupakan beban tersendiri bagi karyawan, karena beban kerja erat kaitannya dengan tingkat stress kerja yang mengakibatkan buruknya prestasi kerja karyawan.

Menurut Anita, Aziz, dan Yunus (2013) hasil penelitian membuktikan bahwa penempatan dan beban kerja karyawan mempunyai hubungan positif dengan motivasi kerja dan peningkatan prestasi kerja karyawan. Penelitian ini memilih objek Hotel Sudi Mampir Blok Songo-Labuhanbatu Selatan yang berada di Jalan Lintas Sumatera Utara, Hotel Sudi Mampir Blok Songo merupakan unit bisnis yang bergerak di bidang kuliner dan jasa penginapan yang menawarkan jasa kepada pelanggan yang berkunjung ke Hotel Sudi Mampir.

Menurunnya prestasi kerja karyawan Hotel Sudi Mampir Blok Songo mempengaruhi tingkat kepuasan kerja dan beban kerja karyawan. Hotel Sudi Mampir Blok Songo dalam kegiatan operasional menerapkan shift kerja, karena pekerjaan dengan shift kerja mengandung beban kerja yang lebih besar dari pekerja standar. Berdasarkan uraian latar belakang masalah yang uraikan, maka dari itu penulis tertarik melakukan penelitian guna memecahkan masalah yang dihadapi manajemen dalam mencapai prestasi kerja secara empiris dengan judul "PENGARUH KEPUASAN KERJA DAN BEBAN KERJA TERHADAP PRESTASI KERJA HOTEL SUDI MAMPIR BLOK SONGO-LABUHANBATU SELATAN".

\section{Tujuan Penelitian}

Berdasarkan uraian permasalahan di atas, adapun tujuan dari penelian ini adalah:

1. Untuk menganalisis pengaruh secara parsial kepuasan kerja terhadap prestasi kerja.

2. Untuk menganalisis pengaruh secara parsial beban kerja terhadap prestasi kerja.

3. Untuk menganalisis pengaruh secara serempak kepuasan kerja dan beban kerja terhadap prestasi kerja.

\section{LANDASAN TEORI \\ Uraian Teoritis \\ Prestasi Kerja}

Menurut Hasibuan

(2009)

menyatakan prestasi kerja adalah suatu hasil kerja yang dicapai karyawan dalam melaksanakan tugas-tugas yang dibebankan kepadanya yang didasarkan atas kecakapan, pengalaman, dan kesungguhan serta waktu.

\section{Pengukuran Prestasi Kerja}

Menurut Bernandin dan Russel (1995:383) dalam kutipan Suhud, Djumadi, Noor (2013) mengemukakan enam kriteria primer untuk mengukur prestasi kerja sebagai berikut:

1. Quality, yaitu merupakan tingkat sejauhmana proses atau hasil pekerjaan kegiatan mendekati kesempurnaan atau tujuan yang diharapkan. 
2. Quantity, yaitu merupakan jumlah yang dihasilkan, misalnya jumlah rupiah, jumlah unit, jumlah siklus kegiatan yang diselesaikan.

3. Timeliness, yaitu merupakan sejauhmana suatu kegiatan diselesaikan pada waktu yang dikehendaki, dengan memperhatikan koordinasi output lain serta waktu yang tersedia untuk kegiatan lain.

4. Cost Effectiveness, yaitu merupakan sejauhmana penggunaan sumber daya organisasi dimaksimalkan untuk mencapai hasil tertinggi atau pengurangan kerugian dari setiap unit penggunaan sumber daya.

5. Need for Supervision, yaitu merupakan sejauhmana seorang pekerja dapat melaksanakan suatu fungsi pekerjaan tanpa memerlukan pengawasan seorang supervisor untuk mencegah tindakan yang kurang diinginkan.

6. Interpersonal Impact, yaitu merupakan sejauhmana pegawai memelihara harga diri, nama baik dan kerjasama diantara rekan kerja dan bawahan.

\section{Pengertian Kepuasan Kerja}

Menurut Robbins (2001) dalam kutipan Wibowo (2014) menyatakan kepuasan kerja adalah suatu sikap umum seorang individu terhadap pekerjaannya. Menurut Koesmono (2006) menyatakan bahwa kepuasan kerja dapat didefinisikan sebagai perasaan dan reaksi individu terhadap lingkungan pekerjaannya.

\section{Pengertian Beban Kerja}

Menurut Sutarto

menyatakan bahwa beban aktivitas satuan organisasi atau beban kerja masingmasing pejabat atau pegawai hendaknya merata sehingga dapat dihindarkan adanya satuan organisasi yang terlalu banyak aktivitasnya dan ada satuan organisasi terlalu sedikit aktivitasnya demikian pula dapat dihindarkan adanya pejabat atau pegawai yang terlalu bertumpuk-tumpuk tugasnya dan ada pejabat atau pegawai yang sedikit beban kerjanya sehingga nampak terlalu banyak menganggur".

\section{Kerangka Konseptual}

Menurut Yuniastuti (2011) kepuasan kerja berpengaruh signifikan terhadap prestasi kerja karyawan. Agar tujuan suatu organisasi dapat terwujud, maka karyawan harus bisa merasakan beban kerja karyawan dalam pekerjaannya agar prestasi kerja dapat meningkat.

Penelitian oleh Anita, Aziz, dan Yunus (2013) bahwa beban kerja dapat mempengaruhi prestasi kerja karyawan. Beban kerja karyawan merupakan sejumlah kegiatan yang harus diselesaikan oleh suatu unit organisasi atau pemegang jabatan secara sistematis dengan menggunakan teknik analisis jabatan, teknik analisa beban kerja, atau teknik manajemen lainnya dalam jangka waktu tertentu untuk mendapatkan informasi tentang efisiensi dan efektifitas kerja suatu unit organisasi. Dari penjelasan keterkaitan antara variabel kepuasan kerja dan beban kerja terhadap prestasi kerja tersebut dapat penulis gambarkan dalam kerangka konseptual sebagai berikut : 


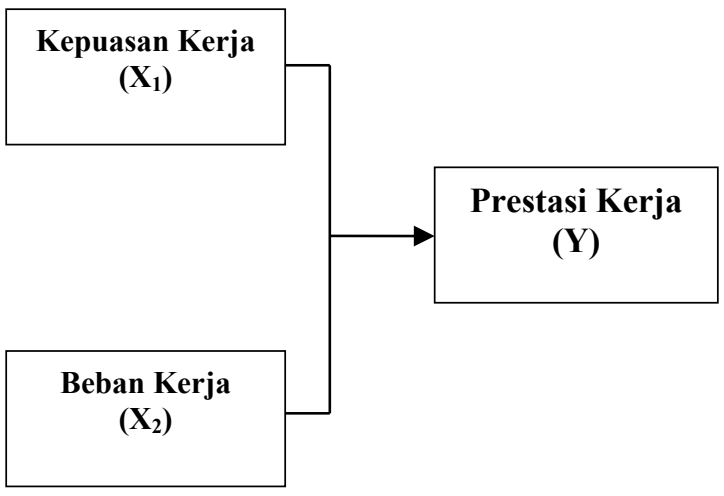

Gambar 1 Kerangka Konseptual

\section{Hipotesis}

Berdasarkan kerangka pemikiran yang telah diuraikan, maka dapat hipotesis dalam penelitian ini adalah :

1. Kepuasan kerja secara parsial berpengaruh positif dan signifikan terhadap prestasi kerja.

2. Beban kerja secara parsial berpengaruh positif dan signifikan terhadap prestasi kerja.

3. Kepuasan kerja dan beban kerja secara serempak berpengaruh positif dan signifikan terhadap prestasi kerja.

\section{METODE PENELITIAN}

\section{Populasi}

dalam sopulasi dan sampel diperlukan mengumpulkan data dari variabel yang diteliti. Populasi adalah wilayah generalisasi yang terdiri atas: obyek/subyek yang mempunyai kualitas dan karakteristik tertentu yang ditetapkan oleh peneliti untuk dipelajari dan kemudian ditarik kesimpulan (Sugiyono, 2009). Populasi penelitian ini adalah karyawan Hotel Sudi Mampir Blok Songo yang berjumlah 40 orang.

\section{Sampel Penelitian}

Sampel adalah bagian atau wakil populasi yang diteliti. Sampel merupakan sebagian dari populasi yang memiliki karakteristik yang relatif sama dan dianggap bisa mewakili populasi (Sugiyono, 2009). Teknik pengambilan sampel untuk menentukan sampel yang akan digunakan dalam penelitian ini menggunakan teknik sampling jenuh (sensus), yaitu metode pengambilan sampel dimana seluruh populasi dianggap sebagai sampel.

\section{Teknik Pengumpulan Data}

Adapun teknik pengumpulan data dalam penelitian ini yaitu :

\section{Observasi}

2. Wawancara

3.Kuesioner

\section{HASIL PENELITIAN}

Analisis regresi linear berganda bertujuan untuk mengetahui pengaruh dari variabel-variabel independen terhadap variabel dependen danat dilihat pada Tabel 1 berikut ini :

Tabel 1

Hasil Regresi Linier Berganda

Coefficients $^{\mathrm{a}}$

\begin{tabular}{|l|c|c|c|c|c|}
\hline \multirow{2}{*}{ Model } & \multicolumn{2}{|c|}{$\begin{array}{c}\text { Unstandardized } \\
\text { Coefficients }\end{array}$} & $\begin{array}{c}\text { Standardized } \\
\text { Coefficients }\end{array}$ & & \\
\cline { 2 - 5 } & B & $\begin{array}{c}\text { Std. } \\
\text { Error }\end{array}$ & Beta & t & Sig. \\
\hline 1 (Constant) & 3.814 & 1.636 & & 2.331 & .025 \\
Kepuasan & .489 & .111 & .488 & 4.389 & .000 \\
Kerja & & .109 & .420 & 3.777 & .000 \\
BebanKerja & .411 & .109 & & & \\
\hline
\end{tabular}

a. Dependent Variable: Prestasi Kerja

Persamaan linier berganda pada model yang digunakan untuk menduga pengaruh tersebut adalah :

$$
Y=3,814+0,489 X_{1}+0,411 X_{2}
$$

\section{Keterangan :}

- Koefisien regresi konstanta sebesar 3,286 mempunyai arti jika ada atau 
variabel kepuasan kerja dan beban kerja, maka prestasi kerja akan sebesar 3,814 .

- Koefisien regresi kepuasan kerja sebesar 0,489 mempunyai arti bahwa setiap terjadi penambahan kepuasan kerja sebesar 0,489 maka prestasi kerja sebesar 1 kali.

- Koefisien regresi beban kerja sebesar 0,411 mempunyai arti bahwa setiap terjadi pengurangan beban kerja sebesar 0,411 maka prestasi kerja sebesar 1 kali.

\section{Pengujian Hipotesis}

Hasil Uji Serempak (Uji F)

Uji F ini dilakukan untuk menguji secara serempak apakah kepuasan kerja dan beban kerja berpengaruh terhadap prestasi kerja, dapat dilihat pada Tabel 2 berikut :

Tabel 2

Hasil Uji Serempak

ANOVA

\begin{tabular}{|l|c|c|c|c|c|}
\hline Model & $\begin{array}{c}\text { Sum of } \\
\text { Squares }\end{array}$ & df & $\begin{array}{c}\text { Mean } \\
\text { Square }\end{array}$ & F & Sig. \\
\hline 1 Regression & 138.252 & 2 & 69.126 & 37.342 & $.000^{\mathrm{a}}$ \\
Residual & 77.748 & 42 & 1.851 & & \\
Total & 216.000 & 44 & & & \\
\hline
\end{tabular}

a. Predictors: (Constant), Beban Kerja, Kepuasan Kerja

b. Dependent Variable: Prestasi Kerja

Berdasarkan Tabel 2

menunjukkan bahwa hasil uji $\mathrm{F}$ sebesar 37,342 dengan tingkat signifikan sebesar 0,000 sedangkan nilai $\mathrm{F}$ tabel sebesar 2,86. Jika dibandingkan nilai Fhitung $(37,342)>$ Ftabel $(2,86)$ pada alpha 5\% maka disimpulkan bahwa secara serempak variabel kepuasan kerja dan beban kerja berpengaruh terhadap prestasi kerja.

\section{Hasil Uji Parsial (Uji t)}

Uji parsial (uji t) dilakukan untuk menguji secara parsial (individu) apakah kepuasan kerja dan beban kerja berpengaruh terhadap prestasi kerja, dapat dilihat pada Tabel 3 berikut :

Tabel 3

Hasil Uji Parsial

Coefficients $^{\mathrm{a}}$

\begin{tabular}{|c|c|c|c|c|c|}
\hline \multirow[b]{2}{*}{ Model } & \multicolumn{2}{|c|}{$\begin{array}{l}\text { Unstandardized } \\
\text { Coefficients }\end{array}$} & \multirow{2}{*}{$\begin{array}{c}\begin{array}{c}\text { Standardized } \\
\text { Coefficients }\end{array} \\
\text { Beta }\end{array}$} & \multirow[b]{2}{*}{$\mathbf{t}$} & \multirow[b]{2}{*}{ Sig. } \\
\hline & B & $\begin{array}{l}\text { Std. } \\
\text { Error }\end{array}$ & & & \\
\hline 1 (Constant) & 3.814 & 1.636 & & 2.331 & .025 \\
\hline Kepuasan Kerja & .489 & .111 & .488 & 4.389 & .000 \\
\hline BebanKerja & .411 & .109 & .420 & 3.777 & .000 \\
\hline
\end{tabular}

a. Dependent Variable: Prestasi Kerja

Berdasarkan Tabel 3 terlihat

bahwa nilai $t_{\text {hitung }}$ untuk variabel kepuasan kerja sebesar 4,389 dengan tingkat signifikansi sebesar 0,000 dan beban kerja sebesar 3,777 dengan tingkat signifikansi sebesar 0,000. Sedangkan untuk nilai $t_{\text {tabel }}$ pada tabel statistik distribusi $\mathrm{t}$ dengan level of test $\alpha=5 \%$ dan $\mathrm{df}_{1}=40$ sebesar 1,685. Berdasarkan kriteria bahwa jika nilai $t_{\text {hitung }}>t_{\text {tabel }}$ yakni $(4,389>1,685) ;(3,777>1,685)$. Maka dapat dinyatakan bahwa secara parsial variabel kepuasan kerja berpengaruh positif dan signifikan terhadap prestasi kerja dan beban kerja berpengaruh positif dan signifikan terhadap prestasi kerja.

\section{Analisis Koefisien Determinasi $\left(\mathbf{R}^{\mathbf{2}}\right)$}

Hasil pengujian koefisien determinasi dapat dilihat dari Tabel 4 sebagai berikut :

\section{Tabel 4}

\section{Hasil Koefisien Determinasi}

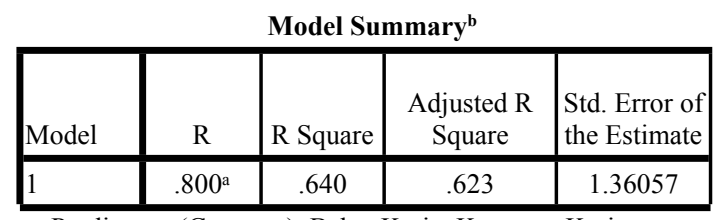

a. Predictors: (Constant), BebanKerja, KepuasanKerja

b. Dependent Variable: PrestasiKerja

Tabel 4 menunjukkan nilai $\mathrm{R}$ Square pada kolom ketiga (angka korelasi atau $r$ yang dikuadratkan) sebesar 0,640. Nilai tersebut berarti bahwa sebesar 
$64,0 \%$ prestasi kerja yang terjadi dapat dijelaskan dengan menggunakan variabel kepuasan kerja dan beban kerja. Sedangkan sisanya sebesar $36,0 \%$ dapat dijelaskan variabel lain yang tidak termasuk dalam model penelitian ini.

\section{Pembahasan}

Berikut ini hasil penelitian yang akan dibahas secara rinci sebagai berikut :

1) Secara parsial kepuasan kerja memiliki nilai $t_{\text {hitung }}>t_{\text {tabel }}$ yakni $(4,389>1,685)$ dengan nilai signifikan $0,000<0,05$ hipotesis Ho diterima yang berarti bahwa kepuasan kerja berpengaruh positif dan signifikan terhadap prestsi kerja. Pada prinsipnya setiap perusahaan selalu mengharapkan karyawannya bekerja secara optimal agar dapat meningkatkan keuntungan dan membantu mempercepat pencapaian tujuan organisasi lainnya. Oleh karena itu untuk mewujudkan harapan tersebut sudah selayaknya apabila perusahaan juga mampu dan bersedia memberikan dorongan yang dapat mengakibatkan karyawan merasa puas terhadap pekerjaannya. Secara parsial beban kerja memiliki nilai $t_{\text {hitung }}>$ $\mathrm{t}_{\text {tabel }}$ yakni $(3,777>1,685)$ dengan nilai signifikan $0,000<0,05$ hipotesis Ho diterima yang berarti bahwa beban kerja berpengaruh positif dan signifikan terhadap prestasi kerja. Pengertian beban kerja adalah sejumlah kegiatan yang harus diselesaikan oleh suatu unit organisasi atau pemegang jabatan secara sistematis dengan menggunakan teknik analisis jabatan, teknik analisa beban kerja, atau teknik manajemen lainnya dalam jangka waktu tertentu untuk mendapatkan informasi tentang efisiensi dan efektifitas kerja suatu unit organisasi.

2) Secara serempak kepuasan kerja dan beban kerja memiliki nilai Fhitung $(37,342)>$ Ftabel $(2,86)$ dengan nilai signifikan $0,000<$ 0,05 hipotesis Ho diterima, maka disimpulkan bahwa secara serempak variabel kepuasan kerja dan beban kerja berpengaruh positif dan signifikan terhadap prestasi kerja. Seorang karyawan akan merasa nyaman dan tinggi loyalitasnya pada perusahaan apabila memperoleh kepuasan kerja sesuai dengan apa yang diinginkan. Kepuasan kerja berhubungan dengan variabelvariabel seperti turnover, tingkat absensi, umur, tingkat pekerjaan, dan ukuran organisasi perusahaan. Analisis Beban Kerja adalah suatu teknik manajemen yang dilakukan secara sistematis untuk memperoleh informasi mengenai tingkat efektivitas dan efisiensi kerja organisasi berdasarkan volume kerja. Volume Kerja adalah sekumpulan tugas/pekerjaan yang harus diselesaikan dalam waktu 1 tahun.

\section{KESIMPULAN DAN SARAN}

\section{Kesimpulan}

Berdasarkan hasil penelitian dan interprestasi pembahasan yang dilakukan, maka diperoleh kesimpulan pada penelitian ini sebagai berikut :

1. Secara parsial kepuasan kerja memiliki 
pengaruh positif dan sangat signifikan terhadap prestasi kerja

2. Secara parsial beban kerja memiliki pengaruh positif dan sangat signifikan terhadap prestasi kerja.

3. Secara serempak kepuasan kerja dan beban kerja memiliki pengaruh positif dan sangat signifikan terhadap prestasi kerja.

\section{Saran}

Berdasarkan hasil analisis dan kesimpulan penelitian, maka diajukan beberapa saran sebagai berikut :

1. Prestasi kerja, kepuasan kerja dan beban kerja masih perlu diadakan perbaikan yaitu pada kepuasan kerja, perlu adanya peningkatan tingkat gaji yang diterima dan juga mengurangi tingkat kesalahpahaman antar rekan kerja yaitu dengan cara meningkatkan komunikasi antar divisi sehingga memperoleh informasi secara menyeluruh, sehingga bisa lebih akrab dan bertukar pengalaman kemudian pada disiplin kerja yaitu perlu adanya peningkatan kedisiplinan kehadiran kerja, khususnya pada waktu tiba bekerja.

2. Untuk meningkatkan prestasi karyawan perusahaan hendaknya perusahaan lebih meningkatkan tigkat kepuasan kerja para karyawan itu sendiri, hal ini dikarenakan kepuasan kerja memiliki pengaruh yang lebih dominan daripada beban kerja.

3. Kebijakan penawasan beban kerja perlu diterapkan kepada seluruh karyawan baik kepada atasan maupun bawahan sehingga kredibilitas perusahaan dapat dipertanggungjawabkan.

\section{DAFTAR PUSTAKA}

Anita, Aziz, dan Yunus. 2013. Pengaruh Penempatan Dan Beban Kerja Terhadap Motivasi Kerja Dan
Dampaknya Pada Prestasi Kerja Pegawai Dinas Tenaga Kerja Dan Mobilitas Penduduk Aceh. Jurnal Manajemen ISSN 23020199 Pascasarjana Universitas Syiah Kuala 11 Pages pp. 6777.

Artadi, Febri Furqon. 2015. Pengaruh Kepuasan Kerja Dan Beban Kerja Terhadap Kinerja Karyawan Pada PT. Merapi Agung Lestari. Skripsi Program Studi Manajemen - Jurusan Manajemen Fakultas Ekonomi Universitas Negeri Yogyakarta.

Handoko. Hani. T. 2007. Mengukur

Kepuasan Kerja. Jakarta.

Erlangga.

Hasibuan, Malayu SP. 2009. Manajemen Sumber Daya Manusia, Edisi Revisi, Bumi Aksara Jakarta.

Koesmono, T. 2005. Pengaruh Budaya Organisasi Terhadap Motivasi dan Kepuasan kerja serta Kinerja Karyawan pada Sub Sektor industry Pengolahan Kayu Skala Menengah di Jawa Timur. Jurnal Manajemen dan Kewirausahaan, Vol.7, No.2

Munandar, Ashar Sunyoto. 2008. Cetakan

Ke 1 Psikologi Industri Dan

Organisasi. Universitas

Indonesia, Jakarta

Permendagri RI. 2008. Tentang Beban

Kerja. Peraturan Mentri dalam

Negeri nomor: 12/2008

Rivai, Veitzal. 2010. Manajemen Sumber

Daya Manusia untuk

Perusahaan. Jakarta: PT. Raja

Grafindo Persada

Robbins SP, dan Judge. 2007. Perilaku

Organisasi, Alih Bahasa Drs.

Benyamin Molan Jakarta :

Salemba Empat 
Sugiyono. 2009. Metode Penelitian Kuantitatif dan Kualitatif. CV.Alfabeta: Bandung.

Sutarto. 2006. Dasar-Dasar Kepemimpinan Administrasi. Yogyakarta: Gajah Mada University Press.

Sutrisno, Edy. 2010. Manajemen Sumber Daya Manusia. Jakarta: Kencana. Prenada Media Group.

Suhud, T., Djumadi, \& Noor, M. (2013). Peningkatan Prestasi Kerja Pegawai Pada Dinas Perhubungan Provinsi Kalimantan Timur. eJournal Administrative Reform, Volume 1 No.2, 590-601

Yuniastuti, Rina Milyati. 2011. Pengaruh Kepuasan Kerja Terhadap Prestasi Kerja Karyawan Pada CV. Organik Agro System Di Bandar Lampung. Jurnal Manajemen dan Bisnis Vol. 1 No. 2 April 2011 : 199-210

Wibowo. 2014. Manajemen Kinerja. Jakarta: PT Rajagrafindo Persada 